УДК 34:614.2

DOI https://doi.org/10.32837/pyuv.v1i3(28).337

T. В. Шлапко
Кандидат юридичних наук,
доцент кафедри адліністративного, господарського права
та фінансово-еконолічної безпеки
Навчально-наукового інституту права
Сулського державного університету

Д.О. Тверитінова

студентка II курсу магістратури

Навчально-наукового інституту права

Сулського державного університету

\title{
ІСТОРИЧНИЙ РОЗВИТОК ВІТЧИЗНЯНОГО ЗАКОНОДАВСТВА У СФЕРІ МЕДИЧНОГО ОБСЛУГОВУВАННЯ НАСЕЛЕННЯ
}

Україна є суверенною, конституційною країною, де Конституція визначена як головний, вищий законодавчий акт. У Конституції закріплені основні принципи та завдання держави, покликаної захищати права своїх громадян. Рівень довіри громадян України, згідно зі статистикою, дуже низький. Більшість принципів, які передбачають створення для громадян України вільного та безоплатного доступу до освіти, медицини, захисту, не діють та не виконуються державними й іншими виконавчими органами влади. Ст. 3 Конституції України проголошує, що людина, її життя і здоров'я, честь і гідність, недоторканність і безпека визнаються в Україні найвищою соціальною цінністю. Ст. 49 Конституції встановлює, що кожен має право на охорону здоров'я, медичну допомогу та медичне страхування; держава створює умови для ефективного і доступного для всіх громадян медичного обслуговування. У державних і комунальних закладах охорони здоров'я медична допомога надається безоплатно [1].

Тому наявна ситуація в умовах введення нового підходу до медичного обслуговування потребує детального розгляду, порівняння й аналізу змін, які нам пропонує держава.

Історію медичного права, правове регулювання надання медичної допомоги, поняття «медичне обслуговування» досліджували такі науковці, як: С. Бугайцов, М. Білинська, Т. Блащук, Ю. Вороненко, В. Віткова, О. Грицко, Т. Грузєва, Л. Жаліло, Д. Карамишев, Н. Кризина, В. Лехан, Н. Мєзєнцева, 3. Надюк та інші.

Мета статті - дослідити історичний розвиток вітчизняного законодавства, яке регулювало порядок здійснення медичного обслуговування, 3 давніх часів до сьогодення на теренах сучасної України, з'ясувати відмінності норм права, які існували в першоджерелах, і тих, які діють сьогодні.

Історія становлення української медицини та розвитку сфери управління медичними заклада- ми, які будь-коли існували на території України, є досить обширною та вагомою частиною розвитку української держави як самостійної, суверенної країни. Історія України налічує декілька періодів, кожний із них має свої відмінності та подібності.

Проаналізувавши історичні джерела, можна виділити п'ять етапів історичного становлення медичної діяльності в Україні:

1) X-XVII ст.;

2) Правління Петра Великого;

3) Розквіт Російської імперії, від середини XVIII до початку XX ст.;

4) Радянський період (1917-1991рp.);

5) Правове становлення та розвиток системи охорони здоров'я в незалежній Україні (з 1991 р. і до сьогодення).

Україна за часів свого існування перебувала у складі різних держав, як-от: Литовське князівство, Австро-Угорська імперія, Російська імперія, Союз Радянських Соціалістичних Республік.

Кожна із цих країн залишила відбиток не тільки в історії нашої держави, але й в баченні народу, його менталітеті, звичаях, правилах поведінки та нормах права. Різне законодавство на теритоpiї країни, яка стала суверенною, вплинуло й на поняття охорони здоров'я, суспільний розвиток, соціальне здоров'я, сферу управління медичними закладами й інше.

Становлення історії української медицини почалося ще 3 описання в літописах діянь монахів-лічців Агапіта, Пантелеймона, Феодосія, які ми можемо вважати одними з перших зачатків для пізніших «словників українських лікарів». Матеріали до історії народної медицини, монастирської, козацької, цехової медицини знаходяться в давніх рукописах і першодруках.

Важливий етап становлення української істоpiї медицини пов'язаний із формуванням новітньої української медицини в Галичині за влади Австро-Угорщини. Уже із зародженням перших 
українських медичних видань і організацій (кінець XIX ст.) з'явилися історичні описи різних проблем медицини, окремих захворювань, способів лікування та попередження недуг, з'явилися перші українські новітні медико-історичні публікації. В опублікованих у Львові працях Свгена Озаркевича (1861-1916 рр.) подані перші відомості 3 історії вивчення та профілактики інфекційних недуг (починаючи від Гіпократа); Володимир Щуровський (1890-1969 рр.) - шеф санітарної бригади Українських січових стрільців, пізніше лікар Української Галицької армії (далі - УГА), опублікував спогади про медицину в УГА; Володимир Білозор (1890-1969 рр.) - лікар Українських січових стрільців і УГА, командант шпиталю в Кам' янці-Подільському, опублікував нариси про медичну службу в роки Визвольних змагань. Максим Музика (1889-1972 рр.) - професор-мікробіолог, у 1920 р. опублікував велику статтю «Розвиток медичної науки і літератури на Україні в 1917-1918 pp.» [2]. У той час існування України розвиток друкарської справи та поява нових історичних джерел позитивно відобразилися на історії становлення медицини, збереженні ї̈ особливостей, письмовому закріпленні її способів та засобів лікування. Негативною стороною даного етапу є те, що такі історичні джерела писалися під впливом іноземних загарбників, і багато хто з істориків та письменників були змушені писати «за принципами державного управління» того правителя, який володів територією України в той чи інший проміжок часу.

Після скасування кріпацтва потреба в лікарях, фельдшерах зростала, бо селяни тепер могли користуватися їхніми послугами. Тому з початком реформ на території Російської імперії медична освіта стала популярна. «Просвіта, і тільки вона, вирішує все, тому що жоден закон, жодна обов' язкова установа не в змозі вплинути на особисте, домашнє життя, і лише вона, просвіта, має силу розбити міцну оболонку невігластва, звичаїв та звичок, які вибудовувалися віками», - зазначив видатний земець, перший санітарний лікар Росії I. Моллесон, який уважав, що лікарі як ніхто інший в ті часи мали великий вплив на розвиток суспільства, привчання людей до санітарії, введення у звичайне життя правил, які допоможуть побудувати в подальшому культурну, здорову й освічену націю [3].

Зняття деяких обмежень у правах на користування медичними послугами позитивно вплинуло на розвиток суспільства, на виведення обізнаності населення про необхідні процедури та правила охорони свого здоров'я на новий рівень, що сприяло розвитку різних верств населення. Але водночас більшість громадян, а особливо мешканців села, не мали змоги та ресурсів для здобуття освіти належного рівня, тому проблеми забезпечення медичними послугами на селі залишалися відкритими ще багато десятиліть.

За часів Російської імперії на теренах України з 1864 р. під тиском ліберального руху й інтелігенції цар Олександр II затвердив «Положение о губернских и земских учреждениях». Згідно із цим документом, створювалися нові земські та повітові органи місцевого самоврядування, до компетенції яких, окрім соціальних, освітніх i господарських повноважень, входило і медичне обслуговування населення. Зрозуміло, що за тих часів медичних установ майже не було. Але земські управи перейняли від «Приказів громадської опіки» дрібні лікарні і всю медичну справу в повітах (53 повітові лікарні з 1000 ліжками). Також разом із повітовими лікарнями в Україні існувала ще й єдина сільська лікарня на 14 ліжок, яка була побудована в історичному місті Батурині особисто першим президентом Імператорської академії наук і останнім гетьманом України графом Кирилом Розумовським ще наприкінці XVIII ст. [3].

Передача деяких повноважень управління в руки земствам та губерніям стала кроком назустріч населенню, що дало можливість здійснювати управління на підконтрольній їм території, а також розвивати ці території та піднімати рівень освіченості населення. Негативними чинниками залишалися вже закріплені в цих структурах принципи управління, коли розвивається місто, але до села розвиток доходить значно повільніше, що спричиняло занепад сільських територій у контексті санітарії та забезпечення населення соціально необхідними ресурсами.

Після періоду земств на територію проросійської України прийшла нова епоха. 3 розвалом Російської імперії Україна змогла відокремитися від Росії та створити нову державу, яку потім проголосили незалежною - Українську Народну Республіку. Цей період в історії нашої країни був невід'ємною частиною розвитку української нації, думки, науки, медицини й інших галузей.

Першим великим медико-історичним дослідженням цього часу є обширна стаття Овксентія Васильовича Корчака-Чепурківського (18571947 рр.) «Основні етапи будування та розвитку вищої медичної школи у Києві за перше десятиліття радянської влади на Україні». Автор - видатний український гігієніст та демограф, професор соціальної та загальної гігієни Київського медичного інституту, один із засновників Української академії наук, перший серед медиків академік дійсний член ВУАН (1921 р.), тісно співпрацював із Михайлом Грушевським. У роки Української національної революції був у числі організаторів медичного факультету Українського державного університету, став його деканом, за Директорії був другим міністром народного здоров'я і опікування України (1919 р.) [2]. 
Коли Україна перебувала у складі Союзу Радянських Соціалістичних Республік (далі - СРСР), законодавство, спрямоване на регулювання сфери охорони здоров'я, Ірунтувалося на Основах законодавства СРСР та інших актах законодавства СРСР про охорону здоров'я. Тобто акти українського законодавства не повинні були суперечити основному закону у сфері охорони здоров'я та базувалися на загальнонаціональних принципах СРСР.

Закон Української радянської соціалістичної республіки було введено в дію в 1971 р. У преамбулі Закону вказується, що здоров'я є одним із найважливіших завдань радянської держави. Соціалістичний устрій спрямований на оздоровлення, розвиток та турботу про громадян держав, які входять до складу радянської держави, покликаний захищати, сприяти підвищенню рівня оздоровлення населення. Система охорони здоров'я населення Української Радянської Соціалістичної Республіки (далі - УРСР) була побудована на принципах безоплатності та надання кваліфікованої медичної допомоги населенню, а також приділяла увагу розвитку фізичної культури, спорту та здоров'ю матері і дитини, як зазначається в самому нормативному акті [4].

Існування одного законодавчого акта у сфері регулювання медицини означало підняття рівня управління та забезпеченості населення медичними послугами як у місті, так і в селі, що сприяло їхньому розвитку.

Відповідно до Конституції УРСР, право на охорону здоров'я мали всі громадяни республіки. Зазначалося, що охорона здоров'я населення була обов'язком усіх державних органів, установ і організацій, зокрема і професійних спілок та інших громадських організацій держави [5]. У даному нормативному акті зазначалося, що для забезпечення та здійснення охорони здоров'я були встановлені спеціальні завдання, які держава повинна була виконувати на належному рівні. Такі завдання передбачали не тільки надання медичної допомоги й обслуговування населення, а ще й спостереження й оздоровлення навколишнього середовища, забезпечення санітарної охорони водойм, грунту й атмосферного повітря.

Керівним органом у сфері охорони здоров'я було Міністерство охорони здоров'я СРСР, яке здійснювало керівництво через Міністерство охорони здоров'я УРСР. На місцях від імені та під контролем Міністерства охорони здоров'я УРСР діяли виконавчі комітети відповідних рад народних депутатів. Тобто, якщо порівняти із сучасними принципами керівництва даною сферою, то ми бачимо, що механізм залишився той самий, окрім того, що Міністерство охорони здоров'я України не підпорядковане іншим міністерствам i є вищим виконавчим органом у сфері охорони здоров'я [4].
Не секрет, що в Радянському Союзі законодавство соціалістичних республік було побудоване на загальносоюзних радянських нормативних актах, а це, на нашу думку, негативно відображалося на розвитку цих республік. Саме тому багато республік після виходу із СРСР опинилися під загрозою зникнення або занепаду, тому що керівництво держав не знало, як потрібно управляти країною, що «позбавилася» найголовнішого керівника, який спрямовував та керував будь-якими діями керівництва республік.

За час існування незалежної України система охорони здоров'я в нашій країні функціонувала за радянськими мірками, нормативними актами, правилами, які були встановлені на той момент розвитку держави і на ту кількість громадян, які проживали на території УРСР. Це була неефективна, непристосована, стара система керування й управління медичною сферою, яка не могла дотримуватися принципів, закріплених у Конституції України для створення нормального, працюючого апарату охорони здоров'я, який би задовольняв вимоги українських громадян [6, с. 11]. Стара система була побудована на тому, що фінансування всієї галузі здійснювалось через органи самоврядування та спрямовувалось в основному на утримання будівель, через що принципи країни та право громадян на безоплатну медичну допомогу, на вільний і рівний доступ до медицини не дотримувалися.

Інтеграція до європейських цінностей торкнулася кожної ланки державного управління, зокрема і галузі охорони здоров'я.

Медичне обслуговування в одному з нормативно-правових актів України визначено як діяльність закладів охорони здоров'я та фізичних осіб-підприємців, які зареєстровані й одержали відповідну ліцензію в установленому законом порядку, у сфері охорони здоров'я, що не обов'язково обмежується медичною допомогою, але безпосередньо пов'язана з її наданням.

У зв'язку з переходом до європейських принципів у 2016 р. була запроваджена реформа медичної сфери обслуговування населення, яка базується на досвіді європейських країн і спрямована на вдосконалення та підвищення рівня медицини, запровадження медичного страхування та надання якісних медичних послуг населенню. Реформа була розроблена разом із міжнародними експертами для врахування всіх нюансів і досвіду європейської системи охорони здоров'я та має особливості, що визначені далі.

По-перше, реформа ділиться на три етапи (на кожний етап виділяється один рік) відповідно до кількості ланок у системі охорони здоров'я: первинна медична допомога, вторинна спеціалізована медична допомога та реорганізація стаціонарної медичної допомоги. 
По-друге, розробники даної реформи визначили, що основним нормативно-правовим актом, який закладає нові принципи медичного обслуговування та надання медичних послуг, є Закон України «Про державні фінансові гарантії медичного обслуговування населення» [7].

По-трете, докорінно змінюється процедура звернення до лікарів, вводиться таке поняття, як «декларація із сімейним лікарем». Декларація має обов'язковий характер для вільної та своєчасної можливості звернення до свого лікаря на випадок хвороби. Наявність такої декларації забезпечує пацієнту безоплатне лікування, можливість консультування зі своїм лікарем у будь-який час, зокрема за допомогою електронного запису, коли пацієнт самостійно в онлайн-режимі обирає час та день відвідування свого лікаря для отримання консультації.

Четверта і важлива особливість - це зміна порядку фінансування й оплати праці лікарів. Основним завданням держави є забезпечення своїх громадян кваліфікованою і безоплатною медичною допомогою та медичним обслуговуванням, тобто створення фінансового захисту на випадок хвороби тощо. Згідно з нововведенням, гроші не будуть виділятися на утримання закладу охорони здоров'я державної чи комунальної форми власності. Заклади охорони здоров'я неприватної форми власності перетворяться на автономних суб'єктів господарювання, які будуть отримувати кошти за результатами своєї діяльності, а заробітна плата лікарю буде виплачуватися з розрахунку того, скільки пацієнтів закріплено за лікарем згідно з реєстром декларацій. Фінансування закладів охорони здоров'я буде здійснюватися через Національну службу здоров'я України (далі - НСЗУ) як розпорядник бюджетних коштів. Під фінансуванням розуміється, що кошти за реально надані медичні послуги буде нараховувати саме НСЗУ, а не медичний заклад чи інший виконавчий орган.

у процесі реформування системи хорони здоров'я було створено і новий орган виконавчої влади - Національну службу здоров'я України. Дана служба створена у грудні 2017 р., а зареєстрована в Міністерстві юстиції України в березні 2018 р. [8]. Служба підпорядкована Кабінету Мiністрів України, її керівником є Міністр охорони здоров'я. Національна служба здоров'я виконує функції єдиного національного замовника медичних послуг та лікарських засобів за програмою медичних гарантій. Кошти, якими вона оперує від імені держави для оплати медичних послуг (більше 100 млрд гривень щороку), зберігаються на казначейських рахунках. Служба не є власником закладів охорони здоров'я та не здійснює управління ними (принцип розмежування функцій замовника і постачальника медичних послуг) [9].
Позитивними сторонами реформування системи медичного обслуговування $\epsilon$ те, що фінансова складова частина тепер простежується в документах, можна контролювати, хто та в яких обсягах надав медичні послуги населенню, за які держава сплачує кошти. Декларування кількості пацієнтів є показником того, що держава запроваджує практичне застосування права на безоплатну медицину, яке закріплене в Конституції України. Негативними моментами є незабезпеченість медичних закладів відповідним матеріально-технічним оснащенням, яке необхідне для надання якісного медичного обслуговування.

Українська медицина розвивалася не одне століття. Під впливом законодавства різних панівних держав склався сучасний український менталітет і укорінилися бачення та поняття захисту здоров'я, медичної допомоги, медичного обслуговування, медичної послуги. Важливий вплив на існуючу систему медичного обслуговування було здійснено під час правління на території України Радянського Союзу. Україна після проголошення незалежності довгий час не реформувала систему охорони здоров'я населення, через що в державі склалися умови, за яких відбувся спад довіри населення до сфери медичного обслуговування, погіршився стан здоров'я українців порівняно з іншими народами та країнами Європи та прилеглих територій. Перехід до європейської форми медичного забезпечення став великим кроком України на шляху становлення та відновлення української медицини. Ухвалення нових нормативних актів, зміна у форматі керування державними та приватними закладами охорони здоров'я, спрямуванні фінансування за отриману медичну допомогу - усе це є великим кроком до відновлення та нормального функціонування сфери української медицини.

\section{Jimepamypa}

1. Конституція України від 28 червня 1996 р. № $254 \mathrm{~K} / 96$-BP. URL: https://zakon.rada.gov.ua/laws/ show $/ 254 \%$ D0 $\%$ BA $/ 96 \%$ D0 $\%$ B2 $\%$ D1 \% 80/paran 4202 (дата звернення: 10.102019 р.).

2. Ганіткевич Я. Про становлення української історії медицини. Онлайн-журнал наукового товариства імені Шевченка. 2010. URL: http://ntsh.org/node/142 (дата звернення: 17.10.2019).

3. Мезенцева Н. Державне регулювання суспільних відносин у галузі охорони здоров'я України: історичні та правові аспекти : автореф. дис. ... канд. наук з держ. упр.: 25.00.01. Київ, 2010. 23 с.

4. Про охорону здоров'я : Закон УРСР від 15 липня 1971 p. № 27-VIII. URL: http://search.ligazakon.ua/ l_doc2.nsf/link1/T710027.html (дата звернення: 01.11.2019).

5. Конституція (Основний закон) Української РСР від 20 квітня 1978 р. Верховна Рада України. URL: https://zakon.rada.gov.ua/laws/show/888-09 (дата звернення: 16.10.2019).

6. Герц А. Медична послуга як об'єкт правового регулювання. Науковий вісник Міжнародного гумані- 
тарного університету. Серія «Юриспруденція». 2015. № 15. T. 2. C. 11-13.

7. Про державні фінансові гарантії медичного обслуговування населення : Закон України від 19 жовтня 2017 р. № 2168-VIII. Верховна Рада України. URL: https://zakon.rada.gov.ua/laws/show/ 2168-19?lang =ru (дата звернення: 01.12.2019).

8. Про утворення Національної служби здоров'я України : постанова Кабінету Міністрів України від 27 грудня 2017 р. № 1101. Верховна Рада України. URL https://zakon.rada.gov.ua/laws/show/1101-2017-\% D0\% BF (дата звернення: 01.12.2019).

9. Реформа системи охорони здоров'я. Національна служба здоров'я України. URL: https://www.kmu.gov.ua/ diyalnist/reformi/rozvitok-lyudskogo-kapitalu/reformasistemi-ohoroni-zdorovya (дата звернення: 20.10.2019).

\section{Анотація}

ІІлапко Т. В., Тверитінова Д. О. Історичний розвиток вітчизняного законодавства у сфері медичного обслуговування населення. - Стаття.

Стаття присвячена аналізу історії розвитку та становлення медичного обслуговування та українського законодавства, яке врегульовувало та на сьогодні регулює сферу надання медичних послуг населенню в Україні. Історія становлення і розвитку медичного права як науки, дисципліни та галузі права бере свій початок iз X століття, часів існування на території України Київської Русі. Історичні джерела права та зводи законів доводять, що регулювання даної сфери діяльності було започатковано саме в ті часи. Медичні послуги та медична діяльність завжди існували та надавалися населенню. Різниця була тільки в тому, що якісна допомога кваліфікованих лікарів надавалася вищим верствам населення (князі, дворяни, феодали), а прості люди отримували медичну допомогу від лікарів-ремісників, знахарів та знахарок. На лікарів, які надавали медичну допомогу людям, поширювалась кримінальна відповідальність у вигляді смертної кари.

У статті проаналізовані відомі сьогодні нормативні акти, які торкалися питання медичного обслуговування населення, починаючи з Х ст., включаючи етапи розвитку українського законодавства за часів перебування України під правлінням різних держав, досліджено вплив іноземних держав на формування та становлення принципів медичного обслуговування, нормативні акти регулювання медичної діяльності, зроблено їх аналіз і порівняно з українськими нормативно-правовими актами, які існують сьогодні. Здійснено історичний екскурс розвитку медицини на території України. Розглянуто визначення медичного обслуговування, ме- дичної послуги. Окрема увага приділяється проведенню в Україні медичної реформи, новоствореним актам законодавства, які регулюватимуть сферу здійснення медичного обслуговування, а також нововведенням в частині управління та фінансування діяльності медичних закладів.

Ключові слова: медицина, медичне право, медичне обслуговування, історія медицини, нормативно-правове регулювання.

\section{Summary}

Shlapko T. V., Tverytinova D. O. Historical development of national legislation in the field of public health services. - Article.

The article is devoted to the analysis of the history of development and formation of health care and the normative legal acts that regulated of medical services provision to the population in Ukraine. The history of the formation and development of medical law as a science, discipline and, directly, the field of law dates back to the 10th century during its existence on the territory of Ukraine in Kyivan Rus.

Historical sources of law prove that the regulation of this sphere of activity was initiated in those days. Medical services and medical activities have always existed and were provided to the population. In those days, medical care was provided only to wealthy people who had high social status in society. Poor people have used folk medicine. A medical error that caused death or the excessive health damage was punished by a death penalty.

In this article there are analyzed the normative acts that touched on the issues of medical service of the population since the X century, including the stages of Ukrainian legislation development during the time of its stay under the influence of different states and acts of foreign law. The influence of foreign states on the formation of the principles of medical activity and the formation of medical services was studied.

The analysis of normative documents regulating the procedure for providing health care and medical services was done in the research process. Was also made comparative analysis of normative legal acts and historical excursion. The scientific article discusses the definition of «medical service of the population in Ukraine». Special attention is paid to carrying out medical reform in Ukraine, newly created legislation, which will govern the sphere of medical care, as well as innovation in management and financing of medical institutions.

Key words: Medical reform, Medical care, Health care, Historical development of medical services, Medical acts of legislation. 